\title{
Kryminał akademicki
}

- (ang. academic murder mystery) - jeden z wariantów tzw. powieści akademickiej (ang. academic novel, campus novel), popularnej w anglosaskiej kulturze literackiej, a w literaturze polskiej występującej sporadycznie. Do głównego wyróżnika gatunkowego (tematycznego) powieści akademickiej, jakim jest życie na uczelni ${ }^{1}$, kryminał akademicki dodaje motyw zbrodni, zazwyczaj morderstwa, oraz fabularny wątek prowadzonego w związku z tym śledztwa. Możliwe są dwa modele takiej fabuły: albo zbrodnia zostaje popełniona w środowisku akademickim, śledztwo zaś prowadzi osoba spoza tego kręgu, albo postacią wiodącą jest detektyw amator (często detektywka), z zawodu naukowiec (przeważnie badacz lub badaczka literatury). Przykładem rozwiązania pierwszego są powieści Colina Dextera (1930-2017) z cyklu Sprawy inspektora Morse'a. Ich bohater, Endeavour Morse, jest inspektorem policji w Oksfordzie, a niektóre z prowadzonych przez niego dochodzeń dotyczą zbrodni popełnionych w college'u - tak jest m.in. w Death Is Now My Neighbour (1996) czy The Daughters of Cain (1994). Na podstawie powieści Dextera powstał popularny serial telewizyjny brytyjskiego kanału ITV. Rozwiązanie drugie zastosowała w powieści Gaudy Night (1935) wybitna przedstawicielka tzw. Złotej Ery brytyjskiej powieści detektywistycznej ${ }^{2}$, a zarazem prekursorka kryminału akademickiego, Dorothy L. Sayers (1893-1957). Z wykształcenia filolożka (dyplom z zakresu filologii klasycznej, języków współczesnych oraz literatury średniowiecznej uzyskała w roku 1920 w oksfordzkim Somerville College ${ }^{3}$ ), pisarka ta weszła na trwałe do dwudziestowiecznej historii literatury brytyjskiej nie tylko jako autorka kryminałów, lecz również jako znakomita poetka, tłumaczka (m.in. Boskiej Komedii Dantego i Pieśni o Rolandzie) i autorka esejów o tematyce filozoficzno-teologicznej.

Bohaterka Gaudy Night (tytuł nawiązuje do akademickiego obyczaju organizowania spotkań absolwentów uczelni; słowo gaudy pochodzi od pieśni Gaudeamus Igitur), autorka kryminałów i detektywka Harriet Vane, występuje w czterech powieściach Sayers. Głównym detektywem amatorem jest bowiem w książkach tej pisarki lord Peter Wimsey prowadzący śledztwo w kilkunastu powieściach i wielu opowiadaniach. Vane i Wimsey pozostają w złożonej relacji uczuciowej, a zarazem konkurują ze sobą jako detektywi. W Gaudy Night Harriet zostaje poproszona przez swą dawną przełożoną z oksfordzkiego college’u o pomoc w wyjaśnieniu serii niemiłych zdarzeń mających miejsce $\mathrm{w}$ tej uczelni (anonimowe listy z pogróżkami, akty wandalizmu). Pod pretekstem prowadzenia badań nad twórczością Sheridana le Fanu, a w istocie po to, by wykryć sprawcę tych czynów, przebywa w college'u przez kilka miesięcy, co staje się w książce okazją do przedstawienia realiów akademickiego życia i skomplikowanych, toksycznych relacji międzyludzkich w tym środowisku. W końcu jednak to nie ona, lecz Peter Wimsey rozwiązuje zagadkę, a w finale powieści oświadcza się Harriet i żeni się z nią. Mimo tak, zdawałoby się, konwencjonalnego zakończenia ważną rolę odgrywa w powieści temat kobiecej walki o niezależność i prawo do edukacji, z którego to powodu Gaudy Night określa się niekiedy mianem pierwszego kryminału feministycznego.

\footnotetext{
${ }^{1}$ Słownik rodzajów i gatunków literackich (nowe wydanie), red. G. Gazda, Warszawa 2012, s. 149 (hasło campus novel autorstwa Wojciecha Nowickiego).

${ }^{2}$ Era ta przypadła na lata dwudzieste i trzydzieste XX wieku. Jej najwybitniejszą przedstawicielką jest Agatha Christie, a wśród kanonicznych autorek kryminałów z tego okresu wymienia się jeszcze Margery Allingham, Josephine Tey (właśc. Elizabeth MacKintosh) oraz Ngaio Marsh.

${ }^{3}$ Sayers ukończyła studia z wyróżnieniem pięć lat wcześniej, w roku 1915, lecz wtedy jeszcze absolwentkom nie nadawano tytułów zawodowych magistra (MA).
} 
Tematyka kryminału akademickiego determinuje pozostałe cechy tej odmiany gatunkowej. Występuje tu bohater indywidualny, który prowadzi śledztwo, oraz bohater zbiorowy, czyli wspólnota akademicka. Przestrzeń jest ograniczona do terenu college'u, kampusu bądź np. miejsca, gdzie odbywa się konferencja naukowa, często obejmuje też prywatne mieszkania wykładowców i studentów. W wymiarze spacjalnym kryminał akademicki staje się więc substytutem angielskiego cosy mystery (co można oddać po polsku jako 'kameralna powieść detektywistyczna'), dobrze znanego z pisarstwa Agathy Christie czy z opartego na książkach Caroline Grahams telewizyjnego serialu Midsomer Murders. W wymiarze temporalnym akcja zostaje podporządkowana harmonogramowi roku akademickiego. Osobliwością kryminału akademickiego, którą dzieli on z powieścią akademicką, lecz która odróżnia go od innych odmian powieści detektywistycznych, jest często w nim występująca i nacechowana semantycznie warstwa odwołań intertekstualnych oraz nawiązań do tematyki naukowej (teorie, metodologie, projekty badawcze).

Zdarza się, że to właśnie różnice i konflikty metodologiczne między uczonymi leżą u podłoża zbrodni będących przedmiotem śledztwa w kryminalnej fabule. Tak dzieje się np. w niektórych powieściach jednej z najwybitniejszych amerykańskich krytyczek feministycznych drugiej połowy XX wieku, Carolyn Heilbrun (1926-2003). Heilbrun od 1963 pisała kryminały pod pseudonimem Amanda Cross ${ }^{4}$, gdyż będąc asystentką na anglistyce w Uniwersytecie Columbia obawiała się, że ryzykuje szansę na etat profesorski, gdyby tego rodzaju działalność pisarska wyszła na jaw. Wykreowana przez nią bohaterka, profesor Kate Fansler, jest literaturoznawczynią z talentem do wykrywania sprawców zbrodni, a także kobietą piękną, elegancką, zamożną i niezależną. Elaine Showalter, autorka napisanej w bardzo osobistej tonacji monografii o powieściach akademickich i - podobnie jak Heilbrun - jedna z twórczyń dwudziestowiecznej krytyki feministycznej, tak charakteryzuje ową postać:

[...] profesorka literatury wiktoriańskiej na „jednym z największych i najbardziej prestiżowych uniwersytetów w Nowym Jorku", która jest kimś w rodzaju bohaterki opery mydlanej - Our Gal Sunday Ligi Bluszczowej. Zawsze smukła Kate pojawia się „ubrana w służbie patriarchatowi”" w modnym prochowcu, eleganckich butach na płaskim obcasie i welurowej garsonce ze złotą broszką w klapie. Gdyby ktokolwiek podjął się ekranizacji tej powieści, mam okropne przeczucie, że w rolę Kate wcieliłaby się Julia Roberts ${ }^{6}$.

[...] a professor of Victorian literature at "one of the New York's largest and most prestigious universities" and a sort of "Our Gal Sunday" of the Ivy League. The ever-willowy Kate makes her appearance, "dressed for the patriarchy", in a fashionable raincoat, elegant flat-heeled shoes, and an ultra-suede suit with a gold pin on the lapel. If anyone made a movie of this novel, I have a horrible suspicion that Kate would be played by Julia Roberts (p. 68-69).

${ }^{4}$ Zob. E. Kraskowska, Akademickie kryminaty Amandy Cross, „Nowa Dekada Krakowska” 2015, nr 1-2.

${ }^{5}$ A. Cross, Death in a Tenured Position, New York 1988, s. 5, 9.

${ }^{6}$ E. Showalter, Wydziałowe wieże. Powieść akademicka i jej źródła (cierpień), przeł. zespół tłumaczy ze specjalności przekładowej Instytutu Filologii Polskiej UAM w Poznaniu, Poznań 2015, s. 95. Cytowany fragment pochodzi z rozdziału przetłumaczonego przez Weronikę Zawadzką i Klaudię Ziewiec. Our Gal Sunday (w przybliżeniu: 'dziewczyńska niedziela') to tytuł radiowej opery mydlanej (emitowanej w latach 1937-1957) o sierocie ze stanu Colorado, która poślubia brytyjskiego arystokratę. Liga Bluszczowa (Ivy League) - powszechnie używane określenie ośmiu najbardziej prestiżowych amerykańskich uniwersytetów, do których należy również macierzysta uczelnia Carolyn Heilbrun, nowojorski Columbia University. E. Showalter, Faculty Towers. The Academic Novel and Its Discontents, Philadelphia 2005. 
Chociaż Kate Fansler pozostaje ostentacyjnie obojętna wobec haseł feministycznych, to jednak niezależność, z jaką funkcjonuje w zmaskulinizowanej kulturze Ligi Bluszczowej, nadaje tej postaci wymiar wywrotowy. Najważniejszą akademicką powieścią kryminalną z jej udziałem jest niewątpliwie Death in a Tenured Position z roku 1981, w której śledztwo toczy się wokół tajemniczej śmierci Janet Mandelbaum, pierwszej kobiety zatrudnionej na etacie profesorskim harvardzkiego wydziału anglistyki. Przedmiotem krytyki jest w tej książce zakamieniały patriarchalizm tego ekskluzywnego środowiska, a w fikcyjnych profesorach literatury dopatrywano się realnych pierwowzorów, m.in. Waltera Jacksona Bate’a, „wybitnego znawc[y] [Samuela] Johnsona [...], najznakomitszego z harvardzkich zrzęd, zawziętego przeciwnika dekonstrukcji i feminizmu"' (“[...] great Johnson scholar Walter Jackson Bate, one of Harvard's most distinguished curmudgeons, an open antagonist of deconstruction and feminism”, p. 71).

Kryminały akademickie pisywał także Robert Bernard Martin (1918-1999; jego pisarski pseudonim to Robert Bernard), profesor Uniwersytetu Princeton. Podobnie jak Heilbrun zajmował się on badaniem i nauczaniem literatury wiktoriańskiej, a jego najbardziej znaną powieścią jest Deadly Meeting z 1970 roku. Tytułowe „śmiertelne spotkanie” odnosi się do corocznej konferencji Modern Language Association (MLA), najważniejszego amerykańskiego stowarzyszenia lingwistów i literaturoznawców. Narratorem powieści jest profesor anglistyki, z którego perspektywy poznajemy historię morderstwa pewnego dziekana, „okrutnego, władczego, nietolerancyjnego flirciarza i straszliwego niedouka"8 [cruel, overbearing, bigoted, philandering, and - worst of all - a critical barbarian, p. 54]. Na marginesie rozważań nad tą powieścią Elaine Showalter napisała:

Kryminały oferują również trochę głębszej satysfakcji, dobrze komponują się z satyrą i o wiele więcej przyjemności daje opis osobistego wroga, który dostaje baty i zniża się do morderstwa, niż próba opisania empatycznej historii życia [...]. Ten gatunek przydaje się również do eksplorowania małych, zamkniętych społeczności, poświęcających dużo czasu na głębokie pasje, które mogą się wydawać trywialne obcym - długo żywione urazy i zobowiązania oraz prawie zapomniane sekrety z przeszłości ${ }^{9}$.

Mysteries also offer some deeper satisfactions, [...] they combine well with satire, and it is more fun to portray your enemy being whacked, or stoopin to muder, than to try to write an emphatetic life story [...]. The genre also lends itself to exploring small, closed societies, with intense passions lavished on matters that seem trivial to outsiders, long-standing grudges and debts, and almost-forgotten secrets from the past (p. 52).

W gronie autorek i autorów akademickich kryminałów znalazła się w latach osiemdziesiątych XX wieku Joan Smith z cyklem o Loretcie Lawson, wykładowczyni literatury angielskiej na Uniwersytecie Londyńskim i feministce, a w latach dziewięćdziesiątych amerykanistka z Uniwersytetu Fordham, Joanne Dobson, twórczyni powieści z kolejną detektywką z tytułem profesorskim, Karen Pelletier. Pisarstwo Dobson Elaine Showalter charakteryzuje z wyraźną kąśliwością:

\footnotetext{
${ }^{7}$ E. Showalter, Wydziałowe wieże..., s. 98.

${ }^{8}$ Tamże, s. 76, tłum. Julia Sworowska.

${ }^{9}$ Tamże, s. 74, tłum. jak wyżej.
} 
We wszystkich swoich książkach Dobson pokazuje szalony obraz Wydziału Filologii Angielskiej na [Uniwersytecie] Enfield, który ma nadzwyczajnie wysoki wskaźnik morderstw, najbardziej seksualnie drapieżnych i pozbawionych skrupułów pracowników na świecie, niezwykłą liczbę samotnych rodziców, opuszczonych dzieci i skrywanych romansów oraz wysoki odsetek okropnych studentów. [...] Wydział [...] ma też pracowników, którzy zajmują się queerem, postmodernizmem, postkolonializmem, postszekspiryzmem, neoszekspiryzmem i animalizmem ${ }^{10}$.

In all her novels, Dobson gives a wicked picture of the Enfield English department, which has an extraordinary high homicide rate, the most sexually predatory and unprincipled male faculty members in the world, an unusual number of single parents, abandoned children, and secret affairs, aln a large percentage of rich, obnoxious student majors. [...] Enfield English also has faculty members in queer studies, postmodernism, postcolonialism, post-Shakespeare studies, neo-Shakespeare studies, and animality (p. 95).

Monografia Showalter ukazała się w 2005 roku i traktuje wyłącznie o książkach napisanych w języku angielskim. Od przełomu XX i XXI wieku podgatunek kryminału akademickiego znacznie się rozwinął i dziś lista nazwisk autorek i autorów tego rodzaju powieści jest już bardzo długa. Na przykład historyczka sztuki Christine Poulson porzuciła obiecującą karierę akademicką w jednym z college'ów w Cambridge na rzecz profitów, jakie przynoszą jej kryminały z Cassandrą James w roli głównej - literaturoznawczynią rozwiązującą zagadki zbrodni popełnianych w Cambridge. Allen Simpson, skandynawista z Uniwersytetu w Minnesocie, pisze pod pseudonimem M.D. Lane kryminały, których akcja rozgrywa się w jego macierzystej uczelni, a śledztwa prowadzi policjantka z kampusowej służby ochrony. Warto również wspomnieć o Anne Fleming, badaczce angielskiego romantyzmu, której powieść Death and Deconstruction (1995) traktuje o morderstwie popełnionym podczas konferencji naukowej odbywającej się w Norman Abbey - klasztorze opisywanym w Pieśni XIII poematu Don Juan Lorda Byrona. Z kolei Amerykanka Sally Wright czyni bohaterem swoich powieści kryminalnych archiwistę (a zarazem weterana II wojny światowej) Bena Reevesa, który w pierwszej powieści cyklu, zatytułowanej Publish and Perish (1997), rozwiązuje zagadkę nagłej śmierci swojego przyjaciela, profesora literatury.

Powyższe wyliczenie można by prowadzić jeszcze długo. Jedno jest pewne - w dziedzinie kryminału akademickiego prym wiodą kobiety: jako autorki i jako bohaterki. Ewentualne wyjaśnienie tego fenomenu to temat na osobny artykuł. Trzeba jednak koniecznie dopowiedzieć, że również pierwszy polski kryminał akademicki jest kobiecego autorstwa. Profesor Zofia Tarajło-Lipowska, bohemistka z Uniwersytetu Wrocławskiego, zadebiutowała jako autorka kryminałów utrzymaną w tonacji satyryczno-groteskowej powieścią pt. Śmierć dziekana. W studni złych emocji (2014). Miejscem akcji jest tu (oczywiście fikcyjny) Instytut Studiów Starożytnych Kuropaskiego Uniwersytetu w Pasikurowicach, ofiarą zabójstwa pada dziekan Mirosław Korbieluch, a jak pisze recenzentka książki: „[p]owieść w krzywym zwierciadle ukazuje absurdy szarej, uczelnianej rzeczywistości" ${ }^{11}$. Komisarz Jacek Cichosz, który skutecznie poprowadził dochodzenie w Śmierci dziekana, rozwiązuje zagadkę kolejnej zbrodni w Kurowicach w najnowszej powieści Zofii Tarajło-Lipowskiej pt. Recykling (2017).

\footnotetext{
${ }^{10}$ Tamże, s. 127, tłum. Joanna Askutja.

${ }^{11}$ A. Urbańczyk, W głębokiej studni, „Forum Akademickie” 2015, nr 3.
} 
O tym, że formuła kryminału akademickiego może być zastosowana w dziele literacko wybitnym, świadczy natomiast przypadek Imienia róży Umberta Eco (1980). Średniowieczny klasztor z labiryntową biblioteką, w którym benedyktyńscy mnisi oddają się kopiowaniu ksiąg teologicznych i filozoficznych, a spór o uniwersalia jest odpowiednikiem współczesnych debat metodologicznych, to nic innego jak zamknięta przestrzeń akademii. Motywy zbrodni są tu związane z emocjami charakterystycznymi dla świata nauki, a bogata sfera wyrafinowanych intelektualnie odwołań intertekstualnych staje się źródłem czytelniczych rozkoszy.

\section{Ewa Kraskowska}




\title{
SŁOWA KLUCZOWE:
}

\author{
AMANDA CROSS
}

intertekstualność

kryminał

powieść akademicka

D o rothy L. S a y e r s

\section{E liza Show alter}

\section{ABSTRAKT:}

Artykuł charakteryzuje specyficzną kombinację powieści akademickiej i powieści kryminalnej, jaką jest kryminał akademicki. Gatunek ten rozwijał się od lat trzydziestych XX wieku w literaturze anglosaskiej i wciąż zyskuje na popularności. Również w Polsce podejmowane są od niedawna próby uprawiania tego rodzaju beletrystyki.

\section{NOTA O AUTORZE:}

Ewa Kraskowska - prof. zw. w Instytucie Filologii Polskiej Uniwersytetu im. Adama Mickiewicza w Poznaniu, literaturoznawczyni, badaczka pisarstwa kobiet oraz problemów przekładu literackiego. Kierowniczka Zakładu Literatury XX Wieku, Teorii Literatury i Sztuki Przekładu. Ostatnio pod jej redakcją ukazała się monografia zbiorowa Polskie pisarstwo kobiet $w$ wielu XX: procesy i gatunki, sytuacje i tematy (Poznań 2015). 